Article

\title{
Marker Assisted Transfer of Stripe Rust and Stem Rust Resistance Genes into Four Wheat Cultivars
}

\author{
Mandeep S. Randhawa ${ }^{1,2, *} \mathbb{1}$, Navtej S. Bains ${ }^{3}$, Virinder S. Sohu ${ }^{3}$, Parveen Chhuneja ${ }^{4}$, \\ Richard M. Trethowan ${ }^{1}$, Harbans S. Bariana ${ }^{1}$ and Urmil Bansal ${ }^{1}$ (D) \\ 1 The University of Sydney Plant Breeding Institute, School of Life and Environmental Sciences, 107 Cobbitty \\ Road, Cobbitty, NSW 2570, Australia \\ 2 International Maize and Wheat Improvement Center (CIMMYT), ICRAF Campus, United Nations Avenue, \\ Gigiri, P.O. Box 1041-00621, Nairobi, Kenya \\ 3 Department of Plant Breeding and Genetics, Punjab Agricultural University, Ludhiana 141027, India \\ 4 School of Agricultural Biotechnology, Punjab Agricultural University, Ludhiana 141027, India \\ * Correspondence: m.randhawa@cgiar.org; Tel.: +254-2072-24661
}

Received: 22 May 2019; Accepted: 26 August 2019; Published: 30 August 2019

\begin{abstract}
Three rust diseases namely; stem rust caused by Puccinia graminis f. sp. tritici (Pgt), leaf rust caused by Puccinia triticina (Pt), and stripe rust caused by Puccinia striiformis $\mathrm{f}$. sp. tritici (Pst), are the most common fungal diseases of wheat (Triticum aestivum L.) and cause significant yield losses worldwide including Australia. Recently characterized stripe rust resistance genes Yr51 and Yr57 are effective against pre- and post-2002 Pst pathotypes in Australia. Similarly, stem rust resistance genes Sr22, Sr26, and Sr50 are effective against the Pgt pathotype TTKSK (Ug99) and its derivatives in addition to commercially important Australian pathotypes. Effectiveness of these genes make them good candidates for combining with known pleiotropic adult plant resistance (PAPR) genes to achieve durable resistance against three rust pathogens. This study was planned to transfer rust resistance genes Yr51, Yr57, Sr22, Sr26, and Sr50 into two Australian (Gladius and Livingston) and two Indian (PBW550 and DBW17) wheat cultivars through marker assisted selection (MAS). These cultivars also carry other rust resistance genes: Gladius carries Lr37/Yr17/Sr38 and Sr24/Lr24; Livingston carries Lr34/Yr18/Sr57, Lr37/Yr17/Sr38, and Sr2; PBW550 and DBW17 carry Lr34/Yr18/Sr57 and Lr26/Yr9/Sr31. Donor sources of Yr51 (AUS91456), Yr57 (AUS91463), Sr22 (Sr22/3*K441), Sr26 (Sr26 WA1), and Sr50 (Dra-1/Chinese Spring ph1b/2/3* Gabo) were crossed with each of the recurrent parents to produce backcross progenies. Markers linked to Yr51 (sun104), Yr57 (gwm389 and BS00062676), Sr22 (cssu22), Sr26 (Sr26\#43), and Sr50 (Sr50-5p-F3, R2) were used for their MAS and markers csLV34 (Lr34/Yr18/Sr57), VENTRIUP-LN2 (Lr37/Yr17/Sr38), Sr24\#12 (Sr24/Lr24), and csSr2 (Sr2) were used to select genes present in recurrent parents. Progenies of selected individuals were grown and selected under field conditions for plant type and adult plant rust responses. Final selections were genotyped with the relevant markers. Backcross derivatives of these genes were distributed to breeding companies for use as resistance donors.
\end{abstract}

Keywords: MAS; markers; stem rust; stripe rust; wheat

\section{Introduction}

Wheat (Triticum aestivum L.) is one of the major food crops in the world and it is continuously threatened by several biotic stresses. Among the significant biotic stresses, rust diseases namely: Stem rust caused by Puccinia graminis f. sp. tritici (Pgt), leaf rust caused by Puccinia triticina (Pt), and stripe rust caused by Puccinia striiformis f. sp. tritici (Pst), are the most common diseases of wheat worldwide. Rust diseases have been causing significant economic losses to wheat production in Australia. Stem 
rust epidemic in the 1973-74 season caused economic losses of A\$200 to 300 million [1]. Epidemics of stem rust and leaf rust in wheat crop in Western Australia in 1999 were estimated to result in A\$50 million in losses [2]. Introduction of a new Pst pathotype in Western Australia has been continuously causing yield losses since its detection in $2002[3,4]$.

The importance of genetic resistance to control rust diseases was first demonstrated by Biffen [5]. Since then, breeding for rust resistance is considered as the most preferred management strategy for rust control. This approach has been successful in reducing losses in Australian wheat growing regions, where rust resistant-wheat cultivars protected grain industry from epidemics since 1960s. The Australian grain industry was estimated to save A \$289 million annually from stem rust, stripe rust, and leaf rust infections through resistance breeding efforts [6].

Long lasting control of rust diseases has been achieved through pyramiding resistance genes in a single genotype [7]. It is however difficult to combine more than two genes in conventional breeding programs, especially when genes to be deployed exhibit resistance against all available rust isolates and produce similar infection types. The detection of marker-gene associations has made marker-assisted gene pyramiding an achievable target in breeding programs [8].

Marker assisted selection (MAS) allows enrichment of positive alleles that condition economic traits at early generations in breeding programs and it is underpinned by the availability of tight marker-trait associations that are highly reproducible, cost-effective and user friendly $[9,10]$. The various approaches presently being used for MAS include marker-assisted backcrossing (MABC), forward selection, MAS-aided doubled haploid $(\mathrm{DH})$ production and enrichment of positive alleles among $\mathrm{F}_{2}$ selections.

Molecular markers linked with Yr51 [11], Yr57 [12], Sr22 [13], Sr26 [14], and Sr50 [15] are available. Genes $Y r 51$ and $Y r 57$ are effective against all currently detected Pst pathotypes in Australia. Although a greenhouse isolate with virulence for $\operatorname{Sr} 50$ was detected in 2014 [15], all three genes (Sr22, Sr26, and Sr50) are effective against the Pgt pathotype TTKSK (Ug99) and its derivatives [16]. This study was planned to transfer rust resistance genes $Y r 51, Y r 57, S r 22, S r 26$, and Sr50 into four wheat cultivars through MAS.

\section{Materials and Methods}

\subsection{Plant Materials}

Wheat cultivars Gladius and Livingston (Australian), and PBW550 and DBW17 (Indian) were chosen as recurrent parents for transfer of stripe rust and stem rust resistance genes. Gladius is a spring wheat cultivar that was cultivated in South Australia and is moderately resistant (MR) to stem rust and moderately resistant to moderately susceptible (MR-MS) to stripe rust. Gladius carries all stage resistance (ASR) genes Lr37/Yr17/Sr38 and Sr24/Lr24 introgressions from Aegilops ventricosa and Thinopyrum elongatum, respectively. Livingston is cultivated in northern New South Wales (NSW) and Queensland and shows MR-MS level of resistance against both stripe rust and stem rust under field conditions. It carries adult plant resistance (APR) genes $L r 34 / Y r 18 / S r 57$ and $S r 2$ in addition to ASR gene Lr37/Yr17/Sr38. PBW550 and DBW17 are high yielding cultivars widely cultivated in North Western Plain Zone (NWPZ) in India and are susceptible to stripe rust. Both PBW550 and DBW17 carry Lr34/Yr18/Sr57 and Lr26/Yr9/Sr31. Seed of Indian cultivars was obtained as a part of Australia-India collaborative project funded by the Australian Centre for International Agricultural Research (ACIAR). Donor sources carrying Yr51, Yr57, Sr22, Sr26, and Sr50 were obtained from the Australian Cereal Rust Control Program (ACRCP) staff (Table 1). 
Table 1. List of plant material used to generate backcross derivatives.

\begin{tabular}{cccc}
\hline Recurrent Parents & Donor Parents & Target Gene & Backcross Progenies \\
\hline & AUS91456 & $Y r 51$ & $\mathrm{BC}_{2} \mathrm{~F}_{2}$ \\
Gladius, Livingston, & AUS91463 & $Y r 57$ & $\mathrm{BC}_{2} \mathrm{~F}_{2}$ \\
PBW550, DBW17 & Sr22/3*K441 & $S r 22$ & $\mathrm{BC}_{1} \mathrm{~F}_{2}$ \\
& Sr26 WA1 & $S r 26$ & $\mathrm{BC}_{1} \mathrm{~F}_{2}$ \\
& Dra-1/Chinese Spring & $S r 50$ & $\mathrm{BC}_{1} \mathrm{~F}_{2}$ \\
\hline
\end{tabular}

\subsection{Pathogen Materials}

The Pst pathotype, 134 E16 A+Yr17+Yr27+, Plant Breeding Institute (PBI) culture number 617 and Pgt pathotype 34-1,2,3,4,5,6,7 (PBI culture number 103) were used to screen respective backcross derivatives along with recurrent parents at seedling stage in the greenhouse. The Pst pathotype 134 E16 A+Yr17+Yr27+ was virulent on $Y_{r} 2, Y_{r} 6, Y_{r} 7, Y_{r} 8, Y_{r} 9, Y_{r 17}, Y_{r 2} 7$, and $Y_{r} A$. The Pgt pathotype 34-1,2,3,4,5,6,7 carried virulence for Sr6, Sr8a, Sr9b, Sr9g, Sr11, Sr15, Sr17, and Sr36.

\subsection{Greenhouse Tests}

Four $\mathrm{F}_{1}$ seeds and 10 to 20 seeds from each backcross $\left(\mathrm{BC}_{1} \mathrm{~F}_{1}, \mathrm{BC}_{2} \mathrm{~F}_{1}\right)$ were sown in $9 \mathrm{~cm}$ pots filled with a potting mixture (pine bark and river sand in the ratio of 2:1). Recurrent parents (Gladius, Livingston, PBW550, and DBW17) and donor parents AUS91456 (Yr51), AUS91463 (Yr57), Sr22/3*K441 (Sr22), Sr26 WA1 (Sr26), and Dra-1/Chinese Spring ph1b/2/3* Gabo (Sr50) were included as controls in respective experiments. Cultivar Morocco was used as the susceptible control. After sowing, pots were maintained in rust-free microclimate rooms at $20^{\circ} \mathrm{C}$. Twenty grams of water-soluble fertilizer Aquasol ${ }^{\circledR}$ was dissolved in 10 liters of tap water and applied to 100 pots. A single application of nitrogenous fertilizer urea was applied at the same rate as Aquasol ${ }^{\circledR}$ to the seven-day old seedlings. Inoculations were performed at the two-leaf growth stage by suspending urediniospores in light mineral oil (Isopar L, $5 \mathrm{mg}$ spores per $10 \mathrm{~mL}$ oil) using a hydrocarbon propellant pressure pack. For stripe rust, the inoculated seedlings were placed under polythene hoods in water filled steel trays and incubated in a dark room at $9-12{ }^{\circ} \mathrm{C}$ for $24 \mathrm{~h}$. Stem rust-inoculated seedlings were incubated under polythene hoods in water filled steel trays in a greenhouse microclimate room at $18-20^{\circ} \mathrm{C}$ for $48 \mathrm{~h}$. Following incubation, seedlings were moved to temperature- and irrigation- controlled greenhouse rooms. Post-inoculation temperatures of $27^{\circ} \mathrm{C}$ and $17^{\circ} \mathrm{C}$ were used for stem rust and stripe rust, respectively. Rust response assessments were made 14 days after inoculation according to scales described in Bariana and McIntosh [17]. Rust resistant selections were made by comparing infection types produced by backcross derivatives with donor sources.

\subsection{Field Tests}

The $\mathrm{BC}_{2} \mathrm{~F}_{2}$ progenies of $Y r 51$ and $Y r 57$, and $\mathrm{BC}_{1} \mathrm{~F}_{2}$ progenies of $S r 22, S r 26$ and $S r 50$ were sown at Karalee (KRL) field site of the University of Sydney Plant Breeding Institute, Cobbitty. Thirty-five seeds from each cross were space $(10 \mathrm{~cm})$ planted at KRL for marker assisted selection. In order to create artificial epidemics, urediniospores of Pgt pathotypes (98-1,2,(3),(5),6 and 34-1,2,7+Sr38), Pt pathotypes $(104-1,(2), 3,(6),(7), 11,13 ; 10-1,3,9,10,11,12$ and 76-3,5,9,10+Lr37) and Pst pathotypes (134 $\mathrm{E} 16 \mathrm{~A}+Y r 17+Y r 27+$ and $110 \mathrm{E} 143 \mathrm{~A}+$ ) were suspended in the light mineral oil (Isopar L) and atomized on experimental rows and susceptible infector rows using an ultra-low-volume applicator (Herbi 4, Microfit ${ }^{\circledR}$, Micron Sprayer Ltd.) during three successive clear evenings.

\subsection{DNA Isolation and Quantification}

Total genomic DNA was isolated from seedlings of all test material following the procedure described in Bansal et al. [18]. Quality and quantity of DNA was estimated using agarose (1\%) 
gel and Nanodrop ND-1000 spectrophotometer (NanoDrop Technologies Inc. Wilmington, NC, USA), respectively. Final dilutions of $30 \mathrm{ng} / \mu \mathrm{l}$ concentration were prepared with double distilled autoclaved water.

\subsection{PCR Amplification and Gel Electrophoresis}

For PCR amplification of SSR and STS markers, assays were performed in $10 \mu \mathrm{L}$ reaction mixture containing $0.2 \mathrm{mM}$ dNTPs, 1xImmolase PCR buffer (Bioline), $0.2 \mathrm{mM}$ each of forward and reverse primer, $30 \mathrm{ng}$ of genomic DNA and $0.2 \mathrm{U}$ of Immolase DNA polymerase (Bioline). PCR amplifications were performed according to published protocols for respective markers (Table 2).

Table 2. List of molecular markers linked with rust resistance genes used in the present study.

\begin{tabular}{|c|c|c|c|c|c|c|}
\hline \multirow[t]{2}{*}{ Gene } & \multirow[t]{2}{*}{ Chromosome } & \multirow[t]{2}{*}{ Marker } & \multirow{2}{*}{$\begin{array}{c}\text { Dominant/Co- } \\
\text { Dominant }\end{array}$} & \multicolumn{2}{|c|}{ Base Pairs/Allele } & \multirow[t]{2}{*}{ Source } \\
\hline & & & & $\begin{array}{l}\text { Donor } \\
\text { Parent }\end{array}$ & $\begin{array}{c}\text { Recurrent } \\
\text { Parent }\end{array}$ & \\
\hline Lr34 & 7DS & $\operatorname{csLV} 34$ & Co-dominant & 150 & 229 & Lagudah et al. [19] \\
\hline $\operatorname{Lr37}$ & 2AS & VENTRIUP-LN2 & Dominant & 252 & Null & Helguera et al. [20] \\
\hline$Y r 51$ & $4 \mathrm{AL}$ & sun104 & Dominant & 225 & Null & Randhawa et al. [11] \\
\hline$Y r 57$ & 3BS & gwm389 & Co-dominant & 150 & 145 or 147 & Randhawa et al. [12] \\
\hline$Y r 57$ & 3BS & BS00062676 & Co-dominant & A:A & G:G & Randhawa et al. [12] \\
\hline$S r 2$ & 3BS & $\operatorname{csSr} 2$ & Co-dominant & $172,112,53$ & 225,112 & Mago et al. [21] \\
\hline Sr22 & 7AL & $\operatorname{cssu} 22$ & Co-dominant & 237 & 335 & Periyannan et al. [13] \\
\hline Sr24 & $3 \mathrm{DL}$ & Sr24\#12 & Dominant & 500 & Null & Mago et al. [14] \\
\hline Sr26 & $6 \mathrm{AL}$ & Sr26\#43 & Dominant & 270 & Null & Mago et al. [14] \\
\hline Sr50 & 1DL.1RS & Sr50-5p-F3, R2 & Dominant & 470 & Null & Mago et al. [15] \\
\hline
\end{tabular}

\subsection{Marker Assisted Selection}

Molecular markers linked with $Y r 51, Y r 57, S r 22, S r 26$, and $S r 50$ were tested on respective backcross material to select seedlings positive for the target gene. Marker assisted selection was performed at each backcross generation. $\mathrm{BC}_{2} \mathrm{~F}_{2} \mathrm{~S}\left(\mathrm{Yr}_{\mathrm{F}} \mathrm{H}\right.$ and $\left.\mathrm{Yr} 57\right)$ and $\mathrm{BC}_{1} \mathrm{~F}_{2} \mathrm{~S}(\mathrm{Sr} 22, \mathrm{Sr} 26$, and $S r 50)$ were tested with markers linked with $L r 34 / Y r 18 / S r 57, S r 24 / L r 24, S r 2$, and $L r 37 / Y r 17 / S r 38$ to select resistance genes carried by recurrent parents. Markers details are listed in Table 2.

\subsection{Chi-Squared Analyses}

Goodness-of-fit of the observed segregation ratios with the expected genetic ratios of phenotypic and genotypic data of $\mathrm{BCF}_{2}$ derivatives was tested using chi-squared $\left(\chi^{2}\right)$ analysis.

\section{Results}

\subsection{Marker Assisted Transfer}

Wheat cultivars Gladius, Livingston, PBW550, and DBW17 were crossed with each of the five donors $Y r 51, Y r 57, S r 22, S r 26$, and $S r 50$ to produce $\mathrm{F}_{1}$ hybrids which were in turn backcrossed with the respective recurrent parent. Marker assisted selection was performed at each generation. Figure 1 illustrates the crossing scheme used for the transfer of $Y r 51$ into Gladius as an example. Similar strategy was applied to the transfer of $Y r 57$, whereas single back cross was used for transfer of $S r 22$, Sr26, and Sr50 into each of the four wheat cultivars. Infection types produced by donor and recurrent parents are presented in Table 3. Details of transfer of each gene into four cultivars are discussed below: 


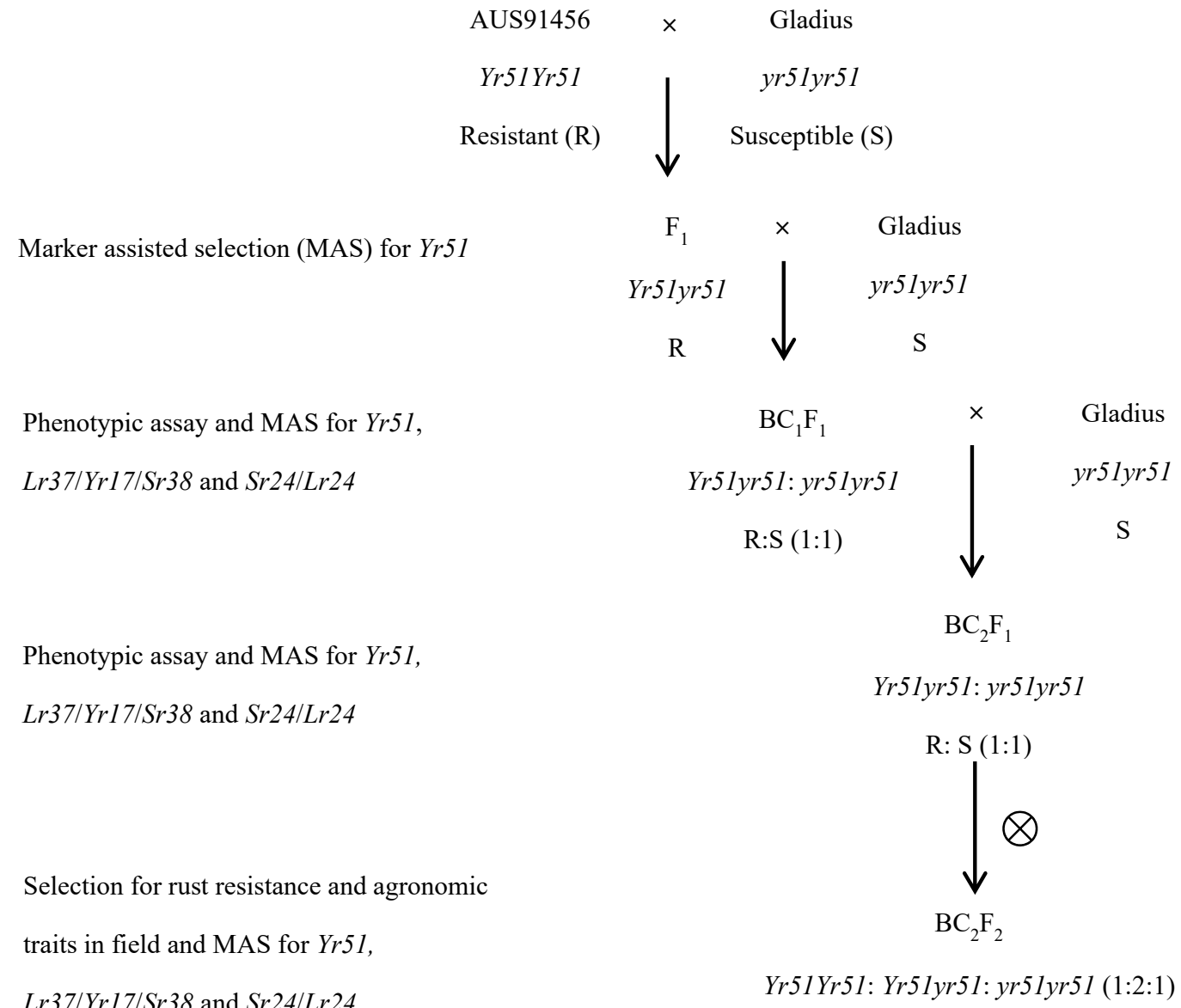

Figure 1. Schematic diagram depicting marker assisted transfer of stripe rust resistance gene $Y r 51$ to Gladius through phenotypic and marker assisted selection at each generation.

Table 3. Pedigree details and infection types produced by donor and recurrent parents, when tested against Puccinia striiformis f. sp. tritici (Pst) pathotype $134 \mathrm{E} 16 \mathrm{~A}+\Upsilon r 17+\Upsilon r 27+$ and Puccinia graminis $\mathrm{f}$. sp. tritici (Pgt) pathotype 34-1,2,3,4,5,6,7.

\begin{tabular}{llcc}
\hline \multicolumn{1}{c}{ Genotype } & \multicolumn{1}{c}{ Pedigree } & \multicolumn{2}{c}{ Infection type } \\
\cline { 3 - 4 } & & 134 E 16A+Yr17+Yr27+ & $\mathbf{3 4 - 1 , 2 , 3 , 4 , 5 , 6 , 7}$ \\
\hline Donor parent & AUS27858/Westonia RIL \#5515-1 & $; n-1 n$ & - \\
AUS91456 & AUS27858/Westonia RIL \#5474-6 & $0 ;$ & - \\
AUS91463 & - & - & $; 1+$ \\
Sr22/3*K441 & - & - & $; 1++\mathrm{c}$ \\
Sr26 WA1 & - & - & \\
Dra-1/Chinese Spring & & & \\
ph1b/2/3* Gabo & (DH)Rac-875/Krichauff//Excalibur & & \\
Recurrent parent & /Kukri/3/RAC-875/Krichauff/4/RAC- & $3+$ & \\
Gladius & 875//Excalibur/Kukri & & \\
& SUN-129-A/Sunvale & $3+$ & $; 1$ \\
Livingston & WH-594/RAJ-3856//W-485 & $3+$ & $; 1$ \\
PBW550 & CMH-79-A-95/3*Ciano79//RAJ-3777 & $3+$ & \\
DBW17 & &
\end{tabular}

\section{2. $Y r 51$}

Yr51-linked dominant marker sun104 was genotyped on $\mathrm{F}_{1}$ hybrids of $Y_{r} 51$ and recurrent parents Gladius, Livingston, PBW550 and DBW17 to ensure identity of the cross. Genotyping of $\mathrm{BC}_{1} \mathrm{~F}_{1}$ seedlings enabled identification of plants carrying the $Y r 51$-linked allele sun $104_{225}$. Similarly, $\mathrm{BC}_{2} \mathrm{~F}_{1}$ 
seedlings were also selected through MAS and those carrying the linked marker allele were advanced to $\mathrm{BC}_{2} \mathrm{~F}_{2}$ stage. $\mathrm{BC}_{1} \mathrm{~F}_{1}$ and $\mathrm{BC}_{2} \mathrm{~F}_{1}$ plants showed 1:1 segregation (sun104 225 : sun104 ${ }_{\text {null }}$ ) at the sun104 locus (Table 4 ).

Table 4. Chi-squared analysis of marker segregation among $\mathrm{BCF}_{1}$ and $\mathrm{BCF}_{2}$ populations.

\begin{tabular}{|c|c|c|c|c|c|c|c|c|}
\hline \multirow[b]{2}{*}{ Cross } & \multicolumn{2}{|c|}{$\mathrm{BC}_{1} \mathrm{~F}_{1}$} & \multicolumn{6}{|c|}{$\mathrm{BC}_{2} \mathrm{~F}_{1}$} \\
\hline & Yr51yr51 & yr51yr51 & $\chi^{2}(1: 1)$ & $p$-value & Yr51yr51 & yr51yr51 & $\chi^{2}(1: 1)$ & $p$-value \\
\hline Yr51/Gladius & 11 & 8 & 0.47 & 0.49 & 22 & 14 & 1.78 & 0.18 \\
\hline Yr51/Livingston & 9 & 8 & 0.06 & 0.81 & 14 & 11 & 0.36 & 0.55 \\
\hline Yr51/PBW550 & 11 & 7 & 0.89 & 0.35 & 9 & 4 & 1.92 & 0.16 \\
\hline \multirow[t]{2}{*}{ Yr51/DBW17 } & 11 & 9 & 0.20 & 0.65 & 6 & 14 & 3.20 & 0.07 \\
\hline & Yr57yr57 & yr57yr57 & & & Yr57yr57 & yr57yr57 & & \\
\hline Yr57/Gladius & 10 & 10 & 0.00 & 1.00 & 11 & 11 & 0.00 & 1.00 \\
\hline Yr57/Livingston & 14 & 6 & 3.20 & 0.07 & 14 & 6 & 3.20 & 0.07 \\
\hline Yr57/PBW550 & 6 & 5 & 0.09 & 0.76 & 8 & 9 & 0.06 & 0.80 \\
\hline \multirow[t]{3}{*}{ Yr57/DBW17 } & 10 & 9 & 0.05 & 0.82 & 7 & 4 & 0.82 & 0.37 \\
\hline & \multicolumn{2}{|c|}{$\mathrm{BC}_{1} \mathrm{~F}_{1}$} & \multicolumn{6}{|c|}{$\mathrm{BC}_{1} \mathrm{~F}_{2}$} \\
\hline & Sr22sr22 & $s r 22 s r 22$ & & & Sr22sr22 & $s r 22 s r 22$ & $\chi^{2}(3: 1)$ & \\
\hline Sr22/Gladius & 4 & 6 & 0.40 & 0.53 & 9 & 7 & 3.00 & 0.08 \\
\hline Sr22/Livingston & 5 & 4 & 0.11 & 0.74 & 13 & 3 & 0.33 & 0.56 \\
\hline Sr22/PBW550 & 3 & 5 & 0.50 & 0.48 & 10 & 6 & 1.33 & 0.25 \\
\hline \multirow[t]{2}{*}{ Sr22/DBW17 } & 7 & 5 & 0.33 & 0.56 & 13 & 3 & 0.33 & 0.56 \\
\hline & Sr26sr26 & Sr26sr26 & & & Sr26sr26 & $s r 26 s r 26$ & & \\
\hline Sr26/Gladius & 5 & 5 & 0.00 & 1.00 & 13 & 3 & 0.33 & 0.56 \\
\hline Sr26/Livingston & 5 & 5 & 0.00 & 1.00 & 10 & 6 & 1.33 & 0.25 \\
\hline Sr26/PBW550 & 4 & 5 & 0.11 & 0.74 & 14 & 2 & 1.33 & 0.25 \\
\hline \multirow[t]{2}{*}{ Sr26/DBW17 } & 3 & 9 & 3.00 & 0.08 & 12 & 4 & 0.00 & 1.00 \\
\hline & Sr50sr50 & sr50sr50 & & & Sr50sr50 & sr50sr50 & & \\
\hline Sr50/Gladius & 7 & 3 & 1.60 & 0.20 & 9 & 7 & 3.00 & 0.08 \\
\hline Sr50/Livingston & 4 & 6 & 0.40 & 0.53 & 10 & 6 & 1.33 & 0.25 \\
\hline Sr50/PBW550 & 4 & 6 & 0.40 & 0.53 & 11 & 5 & 0.33 & 0.56 \\
\hline Sr50/DBW17 & 6 & 6 & 0.00 & 1.00 & 15 & 1 & 3.00 & 0.08 \\
\hline
\end{tabular}

\section{3. $Y r 57$}

Yr57-linked markers gwm389 and BS00062676 were co-dominant, and the Yr57 source carried gwm389 150 and BS00062676 'A:A' alleles. The $\mathrm{F}_{1}$ hybrids involving $Y r 57$ (AUS91463) and recurrent parents Gladius, Livingston, PBW550, and DBW17 were genotyped to ascertain the presence of $Y r 57$ and to exclude the possibility of selfing. DNA from 11 to $20 \mathrm{BC}_{1} \mathrm{~F}_{1}$ seedlings was isolated and tested using markers gwm389 and $B S 00062676 . \mathrm{BC}_{1} \mathrm{~F}_{1}$ seedlings carrying the $Y r 57$-linked alleles were selected and backcrossed to respective recurrent parent to produce $\mathrm{BC}_{2} \mathrm{~F}_{1}$ plants. Again $\mathrm{Yr}$ 57-carrying $\mathrm{BC}_{2} \mathrm{~F}_{1}$ seedlings were selected using markers and advanced to produce $\mathrm{BC}_{2} \mathrm{~F}_{2}$ generation. Segregation of Yr57-linked markers gwm389 and BS00062676 on $\mathrm{BC}_{1} \mathrm{~F}_{1}$ and $\mathrm{BC}_{2} \mathrm{~F}_{1}$ plants fitted to 1:1 ratio (Table 4).

\section{4. $\operatorname{Sr} 22$}

The Sr22-linked marker cssu22 is co-dominant and the $\mathrm{F}_{1}$ plants from all four crosses carried Sr22-linked cssu22 237 allele together with recurrent parent alleles. The $\mathrm{BC}_{1} \mathrm{~F}_{1}$ seedlings were either heterozygous at the cssu22 locus or carried the respective recurrent parent allele (Table 2). Heterozygous $\mathrm{BC}_{1} \mathrm{~F}_{1}$ plants were grown to produce $\mathrm{BC}_{1} \mathrm{~F}_{2}$ generation. Marker cssu22 showed monogenic segregation when tested on backcross derivatives (Table 4). 


\section{5. $\operatorname{Sr} 26$}

The Sr26-linked marker Sr26\#43 follows dominant inheritance and amplifies 270 bp in genotypes carrying this gene. The $\mathrm{F}_{1}$ plants were genotyped to ascertain the presence of $\mathrm{Sr} 26$ and were crossed to the respective recurrent parent. The $\mathrm{BC}_{1} \mathrm{~F}_{1}$ seedlings carrying the $S r 26$-linked allele in all crosses were selected and advanced to $\mathrm{BC}_{1} \mathrm{~F}_{2}$ generation. Monogenic segregation at the Sr26\#43 locus was observed among $\mathrm{BC}_{1} \mathrm{~F}_{1}$ and $\mathrm{BC}_{1} \mathrm{~F}_{2}$ plants (Table 4 ).

\section{6. $\operatorname{Sr} 50$}

The Sr50-linked marker Sr50-5p-F3, R2 amplified 470 bp product in genotypes carrying Sr50 and no product was observed among recurrent parents indicating its dominant nature. Crosses of Dra-1/Chinese Spring ph1b/2/3* Gabo with all four recurrent parents were genotyped to ensure the presence of $S r 50$ in $\mathrm{F}_{1}$ plants and crossed with the respective recurrent parent. $\mathrm{BC}_{1} \mathrm{~F}_{1}$ seedlings carrying the $S r 50$-linked allele were selected and advanced to produce $\mathrm{BC}_{1} \mathrm{~F}_{2}$ families. The marker Sr50-5p-F3, $R 2$ showed monogenic segregation (Table 4).

\subsection{Marker Assisted Selection of Gene Combinations Among $B C F_{2}$ Families}

Bulked seed from marker positive $\mathrm{BCF}_{2}$ families $\left(\mathrm{BC}_{2} \mathrm{~F}_{2}\right.$ for $Y r 51$ and $Y r 57$, and $\mathrm{BC}_{1} \mathrm{~F}_{2}$ for $S r 22$, Sr26, and Sr50) were space planted in the field during 2014 season and inoculated artificially with Pst, $\mathrm{Pt}$, and Pgt pathotypes. While selection for triple rust resistance and agronomic traits were attempted, DNA from 35 plants from each cross was isolated to confirm presence of the target gene. Additional resistance genes carried by recurrent parents are listed in Table 5. These included Lr37/Yr17/Sr38, $L r 34 / Y r 18 / S r 57, S r 24 / L r 24$, and Sr2. Rust resistant and agronomically better backcross progenies of Gladius and Livingston were tested with Lr37-linked marker VENTRIUP-LN2 to select combination of Lr37/Yr17/Sr38 with the gene targeted for backcrossing. The Sr24/Lr24-linked marker Sr24\#12 was used to select plants carrying Sr24/Lr24 in combination with the target gene in crosses of Gladius. The $\mathrm{Sr} 2$-linked marker was monomorphic among parents and therefore progenies carrying $\mathrm{Sr} 2$ were selected using seedling chlorosis linked with this gene. Backcross progenies of Livingston, PBW550, and DBW17 were tested with Lr34-linked marker csLV34 to identify genotypes carrying $L r 34 / Y r 18 / S r 57$ and the target gene. Table 5 lists different combinations of rust resistance genes identified in backcross progenies of four cultivars.

Table 5. Resistance gene combinations observed in crosses with different wheat cultivars.

\begin{tabular}{|c|c|c|c|}
\hline Recurrent Parents & Background Gene (s) & Gene Combinations & Number of Selected Plants \\
\hline \multirow{5}{*}{ Gladius } & \multirow{5}{*}{ Lr37/Yr17/Sr38, Lr24/Sr24 } & Yr51+Lr37/Yr17/Sr38+Lr24/Sr24 & 4 \\
\hline & & $Y r 57+\operatorname{Lr37/Yr17/Sr38}+\operatorname{Lr} 24 / S r 24$ & 7 \\
\hline & & $S r 22+L r 37 / / r 17 / S r 38+L r 24 / S r 24$ & 7 \\
\hline & & $\operatorname{Sr} 26+\operatorname{Lr} 37 / / r 17 / S r 38+\operatorname{Lr} 24 / S r 24$ & 13 \\
\hline & & Sr50 + Lr37/Yr17/Sr38 + Lr24/Sr24 & 8 \\
\hline \multirow{5}{*}{ Livingston } & \multirow{5}{*}{$\begin{array}{l}\text { Lr34//r18/Sr57, } \\
\text { Lr37/Yr17/Sr38, Sr2 }\end{array}$} & $Y r 51+L r 34 / Y r 18 / S r 57+L r 37 / Y r 17 / S r 38$ & 4 \\
\hline & & Yr57 + Lr34/Yr18/Sr57+Lr37/Yr17/Sr38 & 11 \\
\hline & & Sr22+Lr34/Yr18/Sr57+Lr37//r17/Sr38 & 12 \\
\hline & & $\operatorname{Sr} 26+L r 34 / Y r 18 / S r 57+L r 37 / / r 17 / S r 38$ & 2 \\
\hline & & Sr50 + Lr34/Yr18/Sr57+ Lr37//r17/Sr38 & 4 \\
\hline \multirow{5}{*}{ PBW550 } & \multirow{5}{*}{ Lr34/Yr18/Sr57 } & $Y r 51+L r 34 / Y r 18 / S r 57$ & 3 \\
\hline & & $Y r 57+L r 34 / Y r 18 / S r 57$ & 3 \\
\hline & & $S r 22+L r 34 / Y r 18 / S r 57$ & 10 \\
\hline & & $S r 26+L r 34 / Y r 18 / S r 57$ & 4 \\
\hline & & $S r 50+\operatorname{Lr34} / / r 18 / S r 57$ & 4 \\
\hline \multirow{5}{*}{ DBW17 } & \multirow{5}{*}{ Lr34/Yr18/Sr57 } & $Y r 51+L r 34 / Y r 18 / S r 57$ & 3 \\
\hline & & $Y r 57+L r 34 / Y r 18 / S r 57$ & 2 \\
\hline & & Sr22 + Lr34/Yr18/Sr57 & 9 \\
\hline & & Sr26 + Lr34/Yr18/Sr57 & 3 \\
\hline & & Sr50 + Lr34/Yr18/Sr57 & 5 \\
\hline
\end{tabular}




\section{Discussion}

Diverse breeding methodologies are being used for selection of rust resistance in breeding programs. Backcrossing has been considered as an effective method for transferring resistance genes to agronomically superior genotypes as it allows capturing of recurrent parental background. Single backcross approach was used to achieve combinations of APR genes for resistance to rust diseases in wheat [22-24].

Gene-linked markers can be used to select and confirm gene combinations in segregating populations. Numerous reports about useful marker-trait associations for wheat are available. However, the number of publications detailing the practical application of MAS in wheat breeding is limited [25]. Molecular markers can assist in phenotype-neutral selection of traits that are difficult to select phenotypically, environmentally unstable, or are not cost-effective to assess [26]. Being a non-invasive and seed quantity independent alternative to phenotypic based selection, MAS can be applied at any point in a breeding program.

Close marker-trait associations increase the efficiency of MAS. This study demonstrated the usefulness of markers linked with rust resistance genes $Y r 51, Y r 57, \operatorname{Sr} 22, \operatorname{Sr} 26$, and Sr50. MAS was successfully employed to select combination of these genes with all-stage resistance and/or adult plant resistance genes present in recurrent parents. The MAS approach is even more useful in the case of genes that show recessive inheritance. In this study, backcrossing of the recessive gene $Y_{r} 51$ was successfully achieved.

DNA isolation is the most expensive component of MAS and once DNA of a sample is available then markers linked with a range of traits can be genotyped to select a total genotypic package. However, larger population sizes are required to successfully select desirable number of genotypes carrying positive alleles for multiple trait loci. Bonnet et al. [27] estimated size of population for MAS of different number of loci using different breeding methodologies. A much lower number is needed in the case of doubled haploid/recombinant inbred line and single backcross methods.

Discovery of genetically diverse rust resistance loci and their close association with markers has exponentially increased in the last decade through advancement in genotyping technologies [28]. Validation of marker-trait linkages as demonstrated in this study will ensure assembly of the best training populations for genomic selection in wheat to beat environmental influences to increase selection efficiencies in breeding programs. The improved versions of four cultivars have been distributed to Australian and Indian wheat breeders involved in the Australia-India bilateral project funded jointly by the ACIAR and the Indian Council of Agricultural Research (ICAR) for use in respective breeding programs. This study resulted in improvement of stripe rust and stem rust resistance in wheat cultivars when evaluated in Australia and India. These results covered foreground and background selection to deliver triple rust resistant cultivars to farmers.

Author Contributions: H.S.B., U.B. and R.M.T. designed the experiments. M.S.R. performed all experiments and wrote the manuscript. H.S.B. supervised greenhouse and field evaluation of backcross progenies. U.B. supervised marker assays. N.S.B., V.S.S., and P.C. supplied seed of Indian wheat germplasm through collaborative research project and promoted material for releases as cultivars in India. All authors read the manuscript.

Funding: This research was funded by Grains Research and Development Corporation (GRDC) and ACIAR.

Acknowledgments: First author thanks ACIAR for the award of John Allwright Fellowship to pursue PhD study. Financial support from GRDC Australia is highly appreciated.

Conflicts of Interest: The authors declare no conflict of interest.

\section{References}

1. Watson, I.A.; Butler, F.C. Wheat Rust Control in Australia. In Proceedings of the National Conferences and Other Initiatives and Developments, Sydney, Australia; 1984; p. 88.

2. Hills, A.; Dickie, R.; Loughman, R. Wheat rust management begins now. Aust. Grain 1999, 9, 3-5. 
3. Wellings, C.R.; Wright, D.G.; Keiper, F.; Loughman, R. First detection of wheat stripe rust in Western Australia: Evidence for a foreign incursion. Aust. Plant Pathol. 2003, 32, 321-322. [CrossRef]

4. Wellings, C.R. Puccinia striiformis in Australia: A review of the incursion, evolution, and adaptation of stripe rust in the period 1979-2006. Aust. J. Agric. Res. 2007, 58, 567-575. [CrossRef]

5. Biffen, R.H. Mendel's laws of inheritance and wheat breeding. J. Agric. Sci. 1905, 1, 4-48. [CrossRef]

6. Brennan, J.P.; Murray, G.M. Australian wheat diseases-Assessing their economic importance. Agric. Sci. 1988, 1, 26-35.

7. Watson, I.W.; Singh, D. The future of rust resistant wheat in Australia. J. Aust. Inst. Agric. Sci. 1952, 18, 190-197.

8. Paterson, A.H.; Tanksley, S.D.; Sorrells, M.E. DNA markers in plant improvement. Adv. Agron. 1991, 46, 39-90.

9. Gupta, P.K.; Varshney, R.K.; Sharma, P.C.; Ramesh, B. Molecular markers and their applications in wheat breeding. Plant Breed. 1999, 118, 369-390. [CrossRef]

10. Bariana, H.S.; Bansal, U.K.; Basandrai, D.; Chhetri, M. Application of genomics to breed disease-resistant crop varieties. In Genomics and Breeding for Climate-Resilient Crops; Kole, C., Ed.; Springer: Berlin, Heidelberg, Germany, 2013; Volume 2, pp. 291-314.

11. Randhawa, M.; Bansal, U.; Valárik, M.; Klocova, B.; Dolezel, J.; Bariana, H. Molecular mapping of stripe rust resistance gene Yr51 in chromosome 4AL of wheat. Theor. Appl. Genet. 2014, 127, 317-324. [CrossRef] [PubMed]

12. Randhawa, M.; Bansal, U.; Mago, R.; Bariana, H. Mapping of a new stripe rust resistance locus Yr57 on chromosome 3BS of wheat. Mol. Breed. 2015, 35, 1-8. [CrossRef]

13. Periyannan, S.K.; Bansal, U.K.; Bariana, H.S.; Pumphrey, M.; Lagudah, E.S. A robust molecular marker for the detection of shortened introgressed segment carrying the stem rust resistance gene $\mathrm{Sr} 22$ in common wheat. Theor. Appl. Genet. 2011, 122, 1-7. [CrossRef] [PubMed]

14. Mago, R.; Bariana, H.S.; Dundas, I.S.; Spielmeyer, W.; Lawrence, G.J.; Pryor, A.J.; Ellis, G. Development of PCR markers for the selection of wheat stem rust resistance genes Sr24 and Sr26 in diverse wheat germplasm. Theor. Appl. Genet. 2005, 111, 496-504. [CrossRef] [PubMed]

15. Mago, R.; Zhang, P.; Vautrin, S.; Šimková, H.; Bansal, U.; Luo, M.C.; Rouse, M.; Karaoglu, H.; Periyannan, S.; Kolmer, J.; et al. The wheat $\mathrm{Sr} 50$ gene reveals rich diversity at a cereal disease resistance locus. Nature Plants 2015, 1, 15186. [CrossRef] [PubMed]

16. Singh, R.P.; Hodson, D.P.; Huerta-Espino, J.; Jin, Y.; Bhavani, S.; Njau, P.; Herrera-Foessel, S.A.; Singh, P.K.; Singh, S.; Velu, G. The emergence of Ug99 races of the stem rust fungus is a threat to world wheat production. Ann. Rev. Phytopathol. 2011, 49, 465-481. [CrossRef] [PubMed]

17. Bariana, H.S.; McIntosh, R.A. Cytogenetic studies in wheat. XV. Location of rust resistance genes in VPM1 and their genetic linkage with other disease resistance genes in chromosome 2A. Genome 1993, 36, 476-482. [CrossRef] [PubMed]

18. Bansal, U.K.; Hayden, M.J.; Gill, M.B.; Bariana, H.S. Chromosomal location of an uncharacterised stripe rust resistance gene in wheat. Euphytica 2010, 171, 121-127. [CrossRef]

19. Lagudah, E.S.; McFadden, H.; Singh, R.P.; Huerta-Espino, J.; Bariana, H.S.; Spielmeyer, W. Molecular genetic characterization of the Lr34/Yr18 slow rusting resistance gene region in wheat. Theor. Appl. Genet. 2006, 114, 21-30. [CrossRef]

20. Helguera, M.; Khan, I.A.; Kolmer, J.; Lijavetzky, D.; Zhong-qi, L.; Dubcovsky, J. PCR assays for the Lr37-Yr17-Sr38 cluster of rust resistance genes and their use to develop isogenic hard red spring wheat lines. Crop Sci. 2003, 43, 1839-1847. [CrossRef]

21. Mago, R.; Brown-Guedira, G.; Dreisigacker, S.; Breen, J.; Jin, Y.; Singh, R.; Appels, R.; Lagudah, E.S.; Ellis, J.; Spielmeyer, W. An accurate DNA marker assay for stem rust resistance gene $S r 2$ in Wheat. Theor. Appl. Genet. 2011, 122, 735-744. [CrossRef]

22. Bariana, H.S.; McIntosh, R.A. Genetics of adult plant stripe rust resistance in four Australian wheat cultivars and French cultivar Hybride-de-Bersee. Plant Breed. 1995, 114, 485-491. [CrossRef]

23. Singh, R.P.; Huerta-Espino, J.; Rajaram, S. Achieving near immunity to leaf and stripe rusts in wheat by combining slow rusting resistance genes. Acta Phytopathol. Entomol. Hung. 2000, 35, 135-139. 
24. Singh, R.P.; Huerta-Espino, J. The use of 'single backcross, selected bulk' breeding approach for transferring minor genes based rust resistance into adapted cultivars. In Proceedings of the 54th Australian Cereal Chemistry Conference and 11th Wheat Breeders Assembly, Canberra, Australia, 21-24 September 2004; Black, C.K., Panozzo, J.F., Rebetzke, G.J., Eds.; Cereal Chemistry Division, Royal Australian Chemical Institute: Melbourne, Australia, 2004; pp. 48-51.

25. Kuchel, H.; Fox, R.; Reinheimer, J.; Mosioek, L.; Willey, N.; Bariana, H.; Jefferies, S. The successful application of marker-assisted wheat breeding strategy. Mol. Breed. 2007, 20, 295-308. [CrossRef]

26. Koebner, R.M.D.; Summers, W. 21st century wheat breeding: Plot selection or plate detection? Trends Biotechnol. 2003, 21, 59-63. [CrossRef]

27. Bonnet, D.; Hyles, J.; Rebetzke, G. Efficient integration of molecular and conventional breeding methodologies. In Wheat Production in Stressed Environments; Buck, H.T., Nisi, J.E., Salomon, N., Eds.; Springer: Dordrecht, The Netherlands, 2005; Volume 12, pp. 746-753.

28. Bansal, U.; Bariana, H. Advances in identification and mapping of rust resistance genes in wheat. Methods Mol. Biol. 2017, 1659, 151-162. [CrossRef] [PubMed]

(C) 2019 by the authors. Licensee MDPI, Basel, Switzerland. This article is an open access article distributed under the terms and conditions of the Creative Commons Attribution (CC BY) license (http://creativecommons.org/licenses/by/4.0/). 